\title{
21 \\ CSO Modeling in New Haven, Connecticut
}

\author{
Philip Cheung, Henry Goetz and Perrin Niemann
}

The City of New Haven and the New Haven Water Pollution Control Authority operate a wastewater collection and treatment system that serves over 200,000 residents in the cities of New Haven, Woodbridge, Hamden, and East Haven. The system contains twenty-four permitted regulating structures to relieve high flows associated with wet weather events. These structures permit overflows from the combined sewers to local receiving waters. To address the water quality impacts from these overflows, a facilities plan completed in 1981 recommended construction of separate sanitary and storm sewers on a citywide basis. In 1997, the City started to re-evaluate this plan because of changes in regulatory requirements as well as advances in available technologies for the control or treatment of wet weather flows. MOUSE, an Arcview-GIS based dynamic model, was selected to analyze the performance of the combined sewer overflow (CSO) system. Three-month, 6-month, 1-y, and 2-y design storms were simulated to evaluate the performance of the system. In addition, an average rainfall year was simulated to determine the performance of the system under typical rainfall conditions. The statistics for overflow frequencies, overflow volumes, and overflow durations in this average rainfall year were calculated for each overflow regulator. The statistics were then organized according to receiving waters so that the level of impact caused by the CSOs to each receiving water and the priorities for control could be arranged. Color coding of percent utilization of the pipes and available freeboard at each manhole

Cheung, P., H. Goetz and P. Niemann. 2001. "CSO Modeling in New Haven, Connecticut." Journal of Water Management Modeling R207-21. doi: 10.14796/JWMM.R207-21.

(C) CHI 2001 www.chijournal.org ISSN: 2292-6062 (Formerly in Models and applications to Urban Water Systems. ISBN: 0-9683681-4-X) 
using post-processing software provided easy assessment of bottlenecks and flood prone areas. Short-term control alternatives that could maximize the conveyance capacity of the existing system for meeting Nine Minimum Controls as specified by the US EPA were determined. The performance of pumping stations was evaluated, along with whether their operation rules should be modified. Some parts of the New Haven sanitary sewer system had sediment deposits that reduced available flow capacities. A short-term control plan identified quick-fix alternatives such as minor adjustments of overflow weirs and orifices, or pump rates. A long-term control plan including major capital works such as storage tanks or pump station and trunk sewer replacement was developed.

\subsection{Introduction}

The City of New Haven and the New Haven Water Pollution Control Authority (WPCA) operate a wastewater collection and treatment system that serves approximately 130,500 residents in the City of New Haven. Through inter-local agreements, the WPCA also accepts sanitary flow from the Towns of Woodbridge, Hamden, and East Haven (East Haven accepts some wastewater flow from North Branford), which constitutes an additional population of approximately 86,000 .

During dry weather, New Haven's sewer system transports a combination of sanitary flow and base groundwater infiltration to the East Shore Water Pollution Abatement Facility (WPAF). During wet weather, large quantities of stormwater enter the combined sewers. When the sewer system receives more water than it can convey to the WPAF, it becomes overloaded and surcharged. Regulating structures provide some relief by allowing excess flow to overflow from the system and discharge to the receiving waters of New Haven. There are 24 permitted CSO regulators throughout the New Haven system. They are distributed in the sewer system as shown by the triangles in Figure 21.1. Three of them are now closed.

A facility plan that evaluated alternative methods for controlling CSOs was completed in 1981 and updated in 1988 (Cardinal Engineering Associates, 1981 and 1988). The plan evaluated controls required to convey, treat, or store overflows associated with a 10-y storm. The plan concluded that sewer separation was the most cost-effective method of meeting the evaluation criteria. Because of changes in regulatory climate and requirements as well as advances in control technologies, the City decided to re-evaluate their approach. Approximately $35 \%$ of the planned sewer separation had been completed by 1997 when the reevaluation project started. 


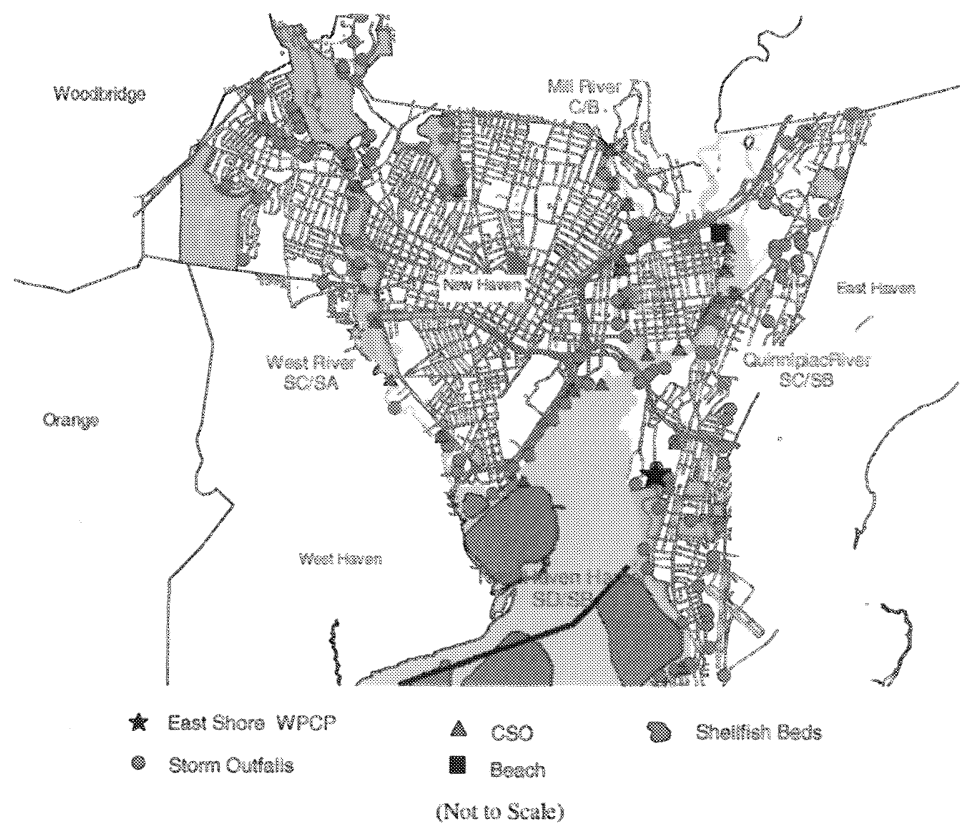

Figure 21.1 Study area and CSOs in New Haven (not to scale).

The objectives of this project were to reduce the overall cost of constructing CSO controls by evaluating the performance of the existing sewer system and develop Short Term and Long Term CSO Control Plans that would be consistent with guidance provided in the US EPA's CSO Control Policy (US EPA, 1994).

The range of tasks of the project included: goals and approach, GIS and model development, flow monitoring program, hydraulic evaluation and characterization, evaluation of nine minimum controls (US EPA, 1995), evaluation of CSO control alternatives, and development of long term CSO control plan. The study is presently evaluating CSO control alternatives and developing the long-term control plan. This chapter focuses on the work and the results completed for model development, hydraulic evaluation and characterization, and preliminary identification of control alternatives.

\subsection{Overview of New Haven System}

The City of New Haven is surrounded by a number of receiving water bodies. As shown in Figure 20.1, these receiving waters include the West River, Mill River, Quinnipiac River, and the New Haven Harbor. The locations of CSO 
outfalls, storm outfalls, and the wastewater treatment facility in relation to beaches and shellfish beds are also shown in the figure.

The Connecticut Department of Environmental Protection has established water quality standards and criteria for determining designated classifications for surface and ground waters (CTDEP, undated). Inland surface waters are designated from $\mathrm{AA}$ to $\mathrm{A}$ through $\mathrm{D}$ and marine waters are designated from SA through SD. Class AA is for existing or proposed drinking water supply; Class A designates that the water body is of potential drinking water supply and recreational uses while Class B is the same as A except that it does not meet drinking water standards. Class $\mathrm{C}$ waters typically result from conditions that are correctable through management of point and non-point sources including urban runoff, combined sewer overflows and wastewater discharges, while Class D waters result from sources of pollution which are not readily correctable such as contamination of sediment or out-of-state sources. The classifications include goals for the restoration of water quality for all waters based on both numeric concentrations for measurable parameters and aesthetic and use criteria that are non-measurable parameters. Where existing water quality does not meet the designated use and water quality goals, the existing water quality is defined and followed by the restoration goal classification. For example, SC/SB designates a water classification of SC, with the goal of attaining SB quality (though some parameters may be designated as unattainable). The dissolved oxygen (DO) minimums for Class A and B waters are generally in the range of 5 to $6 \mathrm{mg} / \mathrm{L}$. For bacteria, Class A waters have a total coliform limit of $100 \mathrm{orgs} / 100 \mathrm{~mL}$, while Class B waters can have fecal coliform concentrations of up to $200 \mathrm{orgs} / 100 \mathrm{~mL}$. Although there are no specifications for BOD and total suspended solids (TSS) concentrations, a limit of $15 \mathrm{mg} / \mathrm{L}$ is generally applicable. For total nitrogen (TN), it is generally believed that a concentration level greater than 0.5 to $1.0 \mathrm{mg} / \mathrm{L}$ may cause adverse effects in river systems.

Table 21.1 summarizes water quality data collected in the West River, Mill River, Quinnipiac River, and New Haven Harbor during dry and wet weather conditions (CH2MHILL, March 2000). The data show that BOD, TSS and DO concentrations met water quality criteria but FC concentrations did not. FC concentrations were quite high during both dry and wet weather. These high concentrations indicate the influence of wet weather discharges such as stormwater and CSOs. However, some of the data were a few decades old and do not represent the improvements in water quality in the receiving waters due to ongoing sewer separation. This is especially true for Mill River. TN concentrations are relatively high and close to the limits.

The specific objective of the computer model for the sewer system was to provide a tool that could be used to analyze the performance of New Haven's 
Table 21.1 Water quality of receiving waters.

\begin{tabular}{|c|c|c|c|c|}
\hline Category & West River & Mill River & Quinnipiac River & New Haven Harbor \\
\hline Land Use & Urban & $\begin{array}{r}\text { Mixed commercial, } \\
\text { industrial, } \\
\text { residential }\end{array}$ & Industrial & Commercial \\
\hline Uses \& Benefits & $\begin{array}{r}\text { Recreation (parks, } \\
\text { canoeing) }\end{array}$ & $\begin{array}{r}\text { Recreation (fishing, } \\
\text { canoeing) }\end{array}$ & Bathing, boating & $\begin{array}{r}\text { Recreation } \\
\text { (boating, parks, } \\
\text { shellfish beds) }\end{array}$ \\
\hline Concerns & CSOs & CSOs & $\begin{array}{r}\text { Industrial } \\
\text { discharges, } \\
\text { wastewater } \\
\text { treatment facilities } \\
\text { upstream }\end{array}$ & Shellfish beds \\
\hline \multicolumn{5}{|l|}{ Water Quality: } \\
\hline $\begin{array}{l}\text { BOD } \\
\text { TSS } \\
\text { FC (dry weather) } \\
\text { FC (wet weather) } \\
\text { DO (dry weather) } \\
\text { DO (wet weather) } \\
\text { TN }\end{array}$ & $\begin{array}{r}<4 \mathrm{mg} / \mathrm{L} \\
\text { no data } \\
10^{3}-10^{4} \text { orgs } / 100 \mathrm{~mL} \\
10^{4}-10^{5} \text { orgs } / 100 \mathrm{~mL} \\
8 \mathrm{mg} / \mathrm{L} \\
5 \mathrm{mg} / \mathrm{L} \\
1.5 \mathrm{mg} / \mathrm{L}\end{array}$ & $\begin{array}{r}<4 \mathrm{mg} / \mathrm{L} \\
\text { no data } \\
10^{4}-10^{5} \text { orgs } / 100 \mathrm{~mL} \\
10^{4}-10^{5} \text { orgs } / 100 \mathrm{~mL} \\
7 \mathrm{mg} / \mathrm{L} \\
5 \mathrm{mg} / \mathrm{L} \\
\text { no data }\end{array}$ & $\begin{array}{r}<4 \mathrm{mg} / \mathrm{L} \\
76 \mathrm{mg} / \mathrm{L} \\
10^{2}-10^{3} \mathrm{orgs} / 100 \mathrm{~mL} \\
10^{4}-10^{5} \mathrm{orgs} / 100 \mathrm{~mL} \\
6 \mathrm{mg} / \mathrm{L} \\
3 \mathrm{mg} / \mathrm{L} \\
1 \mathrm{mg} / \mathrm{L}\end{array}$ & $\begin{array}{r}<4 \mathrm{mg} / \mathrm{L} \\
\text { no data } \\
10^{3}-10^{4} \text { orgs } / 100 \mathrm{~mL} \\
10^{3}-10^{4} \text { orgs } / 100 \mathrm{~mL} \\
7 \mathrm{mg} / \mathrm{L} \\
8 \mathrm{mg} / \mathrm{L} \\
<1 \mathrm{mg} / \mathrm{L}\end{array}$ \\
\hline
\end{tabular}


combined/sanitary sewer system and to evaluate CSO control alternatives for the sewer system. Several steps were taken to develop the computer model, including:

- system inventory: collection of New Haven sewer system and facility data,

- GIS development: storage of system inventory data in electronic databases,

- model development: import of sewer system data into the computer model,

- model calibration: evaluation of the model's performance compared to monitored data and refinement of the model, and

- model verification: verification that the calibrated computer model could predict system performance under a range of conditions.

\subsection{Modeling}

A model of the combined/sanitary system in New Haven was developed in the 1970s using EPA SWMM. Changes in New Haven's combined/sanitary sewer system as a result of the ongoing sewer separation program required the creation of a new model. Recent advancements in computer hardware and modeling software provided an opportunity to develop a more complex model. EPA SWMM, XP-SWMM, MOUSE, and HYDROWORKS were evaluated with criteria such as facility of linking to a geographic information system (GIS), ability to incorporate external hydrographs, ability to provide fully dynamic routing, facility of evaluating control alternatives, cost, vendor's provision of technical support, past experience of staff, and graphical interface capability. MOUSE was selected for the project (CH2MHILL, July 1997) because of its strengths in:

- the capability of linking GIS with the modeling software,

- a strong graphical representation of input and output data,

- an automated network simplification algorithm,

- the lower cost of the hydraulic model and linkage, and

- the ability to incorporate other software in its family to model sediment transport, real-time controls, or receiving water modeling in the future for alternative evaluation, if needed.

It was identified in the early stages of the study that a GIS would be necessary to meet two objectives. The first objective was to manage the amount of data required to develop the computer model. Since the model is capable of directly interfacing with the GIS, the amount of effort required to 
set up MOUSE was reduced. The second objective was to support the City's WPCA efforts to maintain an accurate inventory of their sewer system. As new sewers are built, GIS easily facilitates the update of the entire system.

Figure 21.2 shows the relationships between sewer inventory data, the GIS, and the model. Inventory data of the sewer system were collected and stored in the GIS. The data in the GIS became readily available for addressing the future needs of the City of New Haven and the WPCA. DHI software facilitated extraction of the input data that the model needed from the GIS. Once the data were confirmed to be correct, hydrologic and hydraulic analyses could be performed.
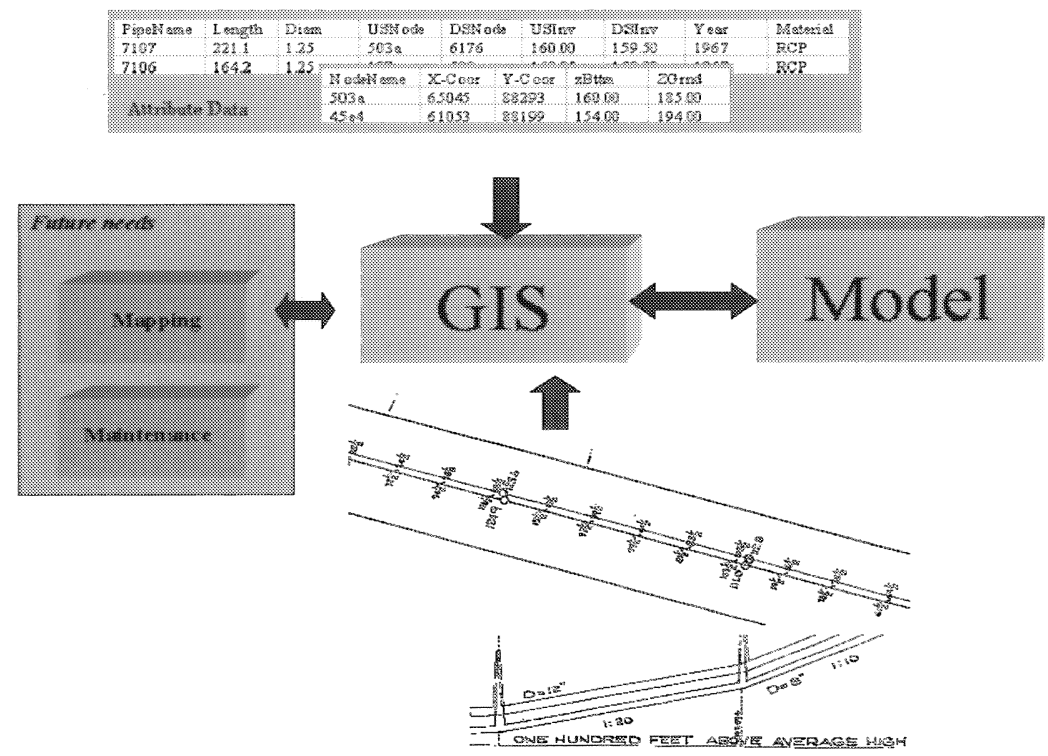

Figure 21.2. GIS and computer model link.

A key step in GIS development was the design of a good GIS database structure that facilitates accessing, transferring, or adding data in the future. Besides providing input data to the computer model, the GIS database could be linked to operation and maintenance schedules and could be used to track the status of sewer construction projects. The first step in this project was to collect graphic data related to the sanitary sewer and storm sewer facilities in New Haven and archive the data in the GIS. This included the manholes and sewers in both the storm and combined/sanitary systems. In addition to the sewer system facilities, a variety of other graphic data-such as land cover, population census tracts, and areas with sewer separation-that were required to build the models was also obtained and stored in the GIS. 
Table 21.2 lists the various facility coverages that were created as part of this project (CH2MHILL, December 1998). There were 8,855 combined and sanitary sewer segments contained in the SANLINK coverage, totaling approximately $400 \mathrm{~km}$ in length, and 6,168 existing and proposed storm sewer segments contained in the STMLINK coverage, totaling approximately $260 \mathrm{~km}$. When the data were being digitized and transferred to the GIS, database queries were conducted to identify missing or questionable data attributes. Each item was checked against strip maps to ensure that the information was transferred correctly and completely. In some cases, additional mapping was needed to solve the discrepancy. For the remaining questions, a survey team obtained the required data in the field.

Table 21.2 ArcInfo sewer system coverages.

\begin{tabular}{lll}
$\begin{array}{l}\text { Coverage } \\
\text { Name }\end{array}$ & Description & Feature \\
\hline SANNODE & $\begin{array}{l}\text { Sanitary sewer manholes, blind connections, pump station } \\
\text { wetwells, system outfalls }\end{array}$ & Point \\
SANLINK & Sanitary sewers, pumps, forcemains, weirs, orifices & Line \\
STMNODE & Storm sewer manholes, blind connections, system outfalls & Point \\
STMLINK & Storm sewers & Line \\
NHSUB & Sewershed subcatchments & Polygon \\
STMCB & Catchbasins & Point \\
STMLAT & Catchbasin laterals & Line \\
SANCR & Location of identified cross connections, valve chambers & Point \\
IMPCOV & Impervious cover & Polygon \\
xX.TIF & $\begin{array}{l}\text { 21 images for base map purposes (xx refers to the integer } \\
\text { map name, e.g. "45.TIF") }\end{array}$ & Raster Image \\
&
\end{tabular}

The first priority for meeting the Nine Minimum Control plan as stated by the US EPA (US EPA, 1995) was to optimize the performance of the combined and sanitary sewer system so that overflows could be reduced. As part of the optimization analysis, pump station capacities and their operating procedures in relation to the dynamics of the combined and sanitary sewer system were analyzed. There were sixteen pump stations in the New Haven hydraulic model. For this project, the forcemains were simulated to provide a better estimation of the pressure head and hydraulic grade line in the sewer system. The pump capacities were specified as functions of the water levels in the pump wet wells. The headwork facilities at two of the major pump stations in New Haven, Boulevard and East Street, were added to the model to provide more accurate simulation of the hydraulic characteristics. Gates, weirs, and bar screens at 
these two major facilities were included. For example, a sluice gate restricting the influent pipe was added to the model at the Boulevard pump station inlet. The gate provided a computed 59\% reduction in flow area (approximately $41 \%$ open). An equivalent pipe was substituted for the gate by equating head losses through the gate to head losses in a pipe flowing full. Similarly, head losses through the bar screens were added.

Another modeling consideration was the presence of sediment in some pipes that have relatively flat grades. The problem was chronic for some of these pipes as their bottom inverts have permanent sediment. Since the sewers contained in the GIS database reflected only the information contained on strip drawings, they could represent only the original clean condition and not field conditions. Through discussions with City staff, areas with chronic sedimentation problems were identified. Approximate sediment depths that had been reported by staff and by the flow monitoring sub-consultant during the monitoring program were compiled, and some field surveys were conducted. Upon completion of the surveys, the sediment profile along the interceptor was prepared. The effect of sediment deposition is reduced flow area. Therefore, pipe cross sections were modified according to the depth of sediment reported. Figure 21.3 shows the effect of sediment on the cross section of an egg-shaped sewer. The new sections that represent sewers with chronic sediment deposition were added to the GIS database.

The overflow regulators in New Haven are primarily weirs. Weirs connect two nodes together and pass flow between them according to the equation that simulates flow over a weir. There were seventeen weirs in the New Haven hydraulic model, located at most of the CSO regulators. Boundary conditions
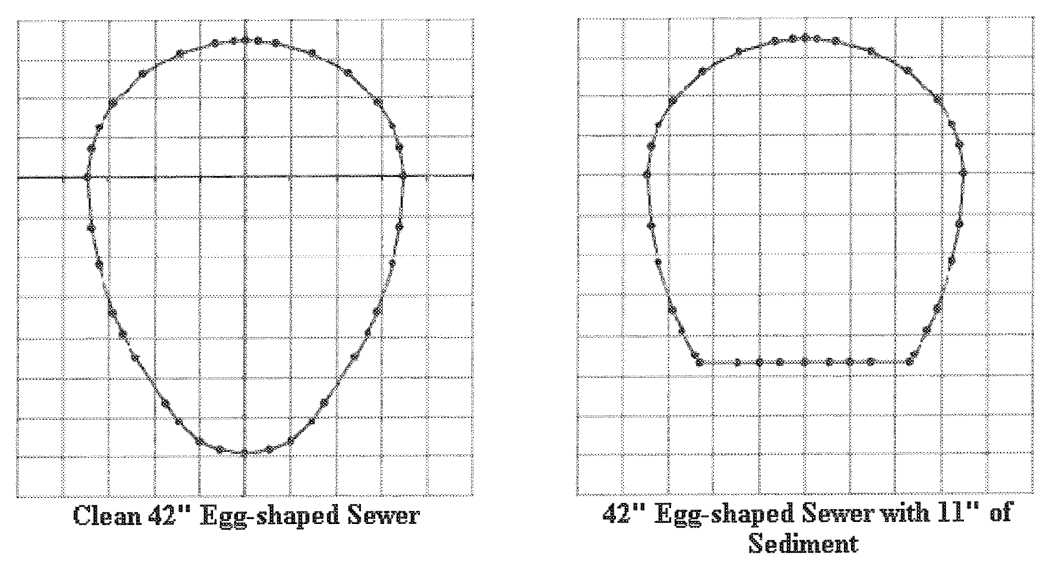

Figure 21.3 Reduced pipe cross-sections due to sediment. 
such as tidal elevations and outfalls with tide gates were specified in the model. Non-return valves were used to prevent water from flowing into the system at outfalls protected by tide gates.

Figure 21.4 shows the schematic of the model.

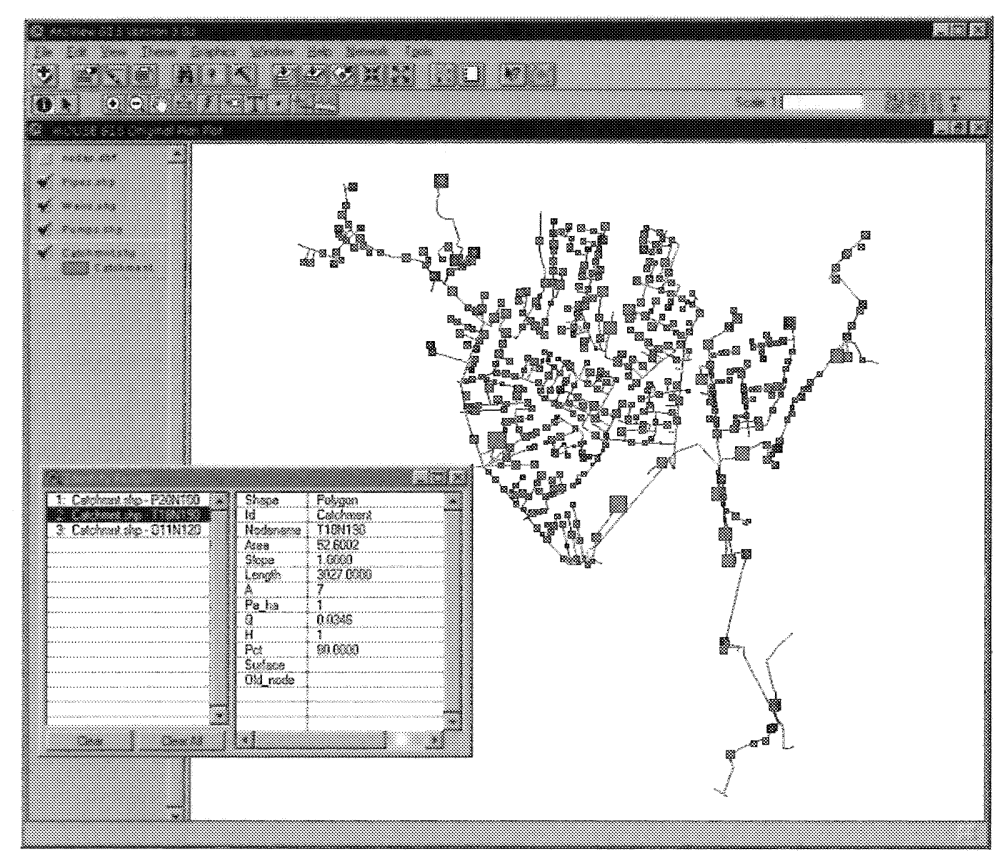

Figure 21.4 Model for New Haven.

\subsection{Model Calibration and Results}

The primary purpose of calibrating and validating a model against measured data is to assure that it provides a realistic simulation. The first step in calibrating the New Haven model was to ensure that the dry weather flow was modeled correctly. Observed data and model results for dry weather periods were compared to ensure that base sanitary flow and groundwater infiltration were realistically simulated. Once significant differences in the observed and modeled dry weather flow data were resolved, the calibration focused on wet weather flows and the modeled system conveyance characteristics. A range of wet weather events was compared to ensure that the system's observed wet weather characteristics were realistically simulated in the model. In many cases, the initial values used in the model's development produced reasonable results and no calibration adjustments were required. 
Throughout the process, when significant differences were noted between the observed and modeled data, additional investigations were performed and/or meetings were held with City operations staff to discuss them. In most cases, specific reasons were identified for the discrepancies and, when necessary, the model or metering data was corrected to address these issues. Examples of issues which were resolved in this manner include: recycled flows at the WPAF meters, pump station operating rules, additional flow sources from outside the City limits, tidal impacts, and sediment within the interceptors. In cases where no satisfactory resolution could be reached, potential sources of error were identified and recommendations for further field work were made.

Thirty flow meters were installed in interceptors and overflow pipes to measure in-system flows and estimate overflow volumes, frequencies, and durations. Three storm events were selected for calibration of the models. For these events, flows at many points in the sewer system were compared with modeled flows. Flow data for the wastewater treatment facility (WPAF) and three major pump stations (Boulevard, East Street, and East Shore) were acquired for verification. As well, there were several flow meters installed at points along the boundaries of New Haven with Woodbridge, Hamden, and East Haven to gage the flows coming from these communities. There were twelve of these meters in operation (CH2MHILL, March 1998).

One goal of the dry weather flow model was to assess the ability of the sewer system to provide a self-cleansing scour velocity. Failure to reach scouring velocities (approximately $0.5 \mathrm{~m} / \mathrm{s}$ ) can lead to sediment deposition, which may result in the loss of system capacity and possible dry weather overflows. A well-calibrated dry weather flow model can help pinpoint troublesome spots in the sewer system and provides a basis for calibrating the model to wet weather conditions. Four sites did not show good agreement between the measured and modeled flows initially. The problems were resolved by adding inflows from an external area that was missed in the initial model and subtracting recycled flows from the WPAF flow data.

Figure 21.5 shows an example calibration plot of the total dry weather flows modeled and the observed DWF at the wastewater treatment facility. The overall dry weather flow pattern for the entire sewershed closely resembled the metered data.

The process used to calibrate the model for wet weather conditions was the same as that followed for dry weather: realistic values were applied, the model was run, differences between the model and meters were noted, reasons for the discrepancies were sought, and the model was adjusted based on the findings. Several iterations of this process were used to refine the model. Three calibration storms were chosen from the monitoring program during the fall of 1997 (S1, S2, and S3). However, these storms did not exceed a 6-month return 
period. It was decided that additional storms should be evaluated. Four additional storms were selected to provide a wider range of volumes and intensities. This ensured the model's ability to simulate changing storm sizes, seasons, and antecedent conditions, and using a range of storms would help explain where and under what storm conditions overflows would occur.

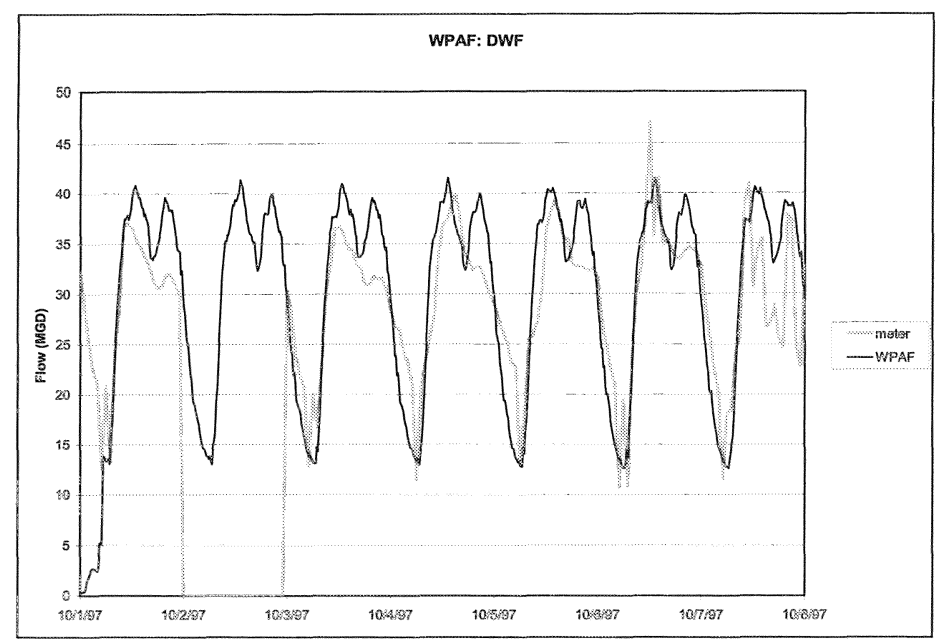

Figure 21.5 Dry weather flow calibration (meter: measured flows, WPAF: modeled flows).

Figures 21.6 to 21.8 show the comparison of simulated flows (WPAF) and the metered flows for the three storm events at the wastewater treatment facility. Flows at this location represent the contribution from the entire sewershed. Figure 21.6 shows the hydrographs for storm S1, which was a very small rainfall that produced only minor wet-weather effects on the sewer system (near December 1, 1997). The model did not generate noticeable wetweather flows in the system.

The other two storms, S2 and S3 as shown in Figures 21.6 and 21.8, had produced more significant wet-weather flows. In general, good agreement between metered and modeled flows was obtained at the wastewater treatment facility. The flows measured before and after the storm closely matched the modeled flows, and in general, the model predicted storm conveyance very well.

One of the applications of the model was to run a simulation for an average year to determine the effects of antecedent conditions and multiple events on overflows and related water quality (CH2MHILL, March 2000). The continuous simulation was run in twelve segments of approximately one-month 


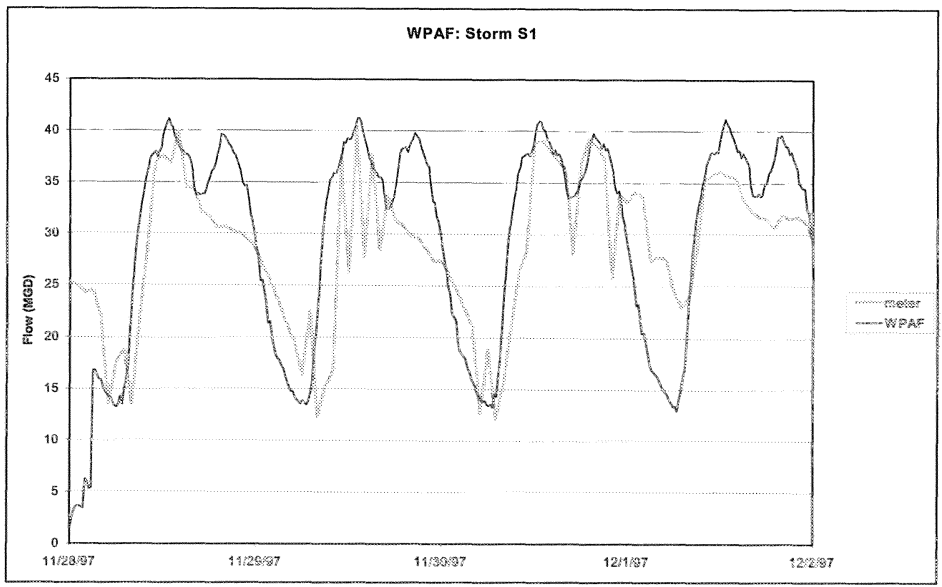

Figure 21.6 Calibration of Storm 1 (meter: measured flows, WPAF: modeled flows).

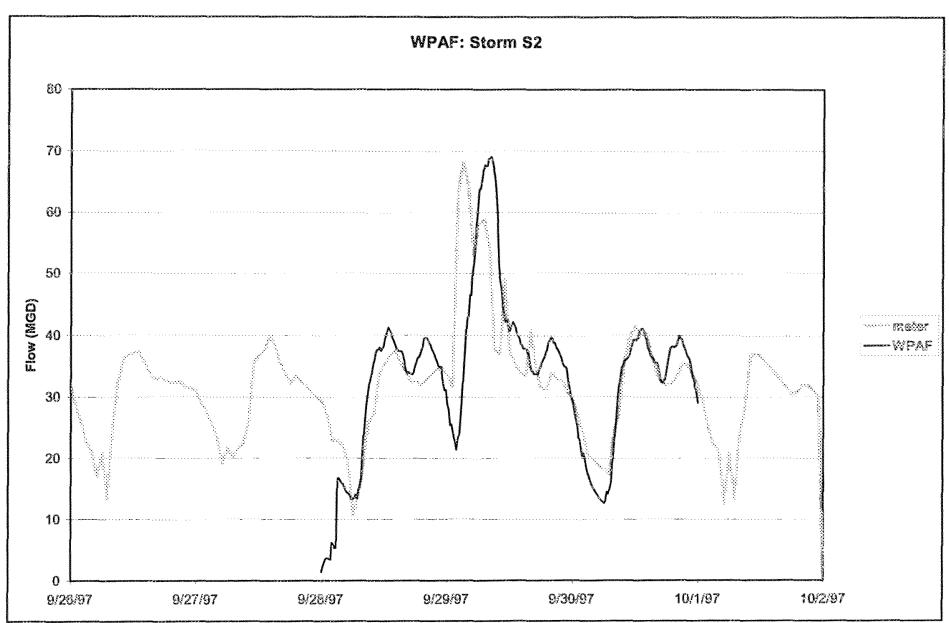

Figure 21.7 Calibration of Storm 2 (meter: measured flows, WPAF: modeled flows).

simulation time each to facilitate debugging of the model results, with the hydrographs added back together at the end. Each of these twelve simulations took approximately $60 \mathrm{~h}$ on a 400-MHz computer. The year 1967 was chosen to represent an average year based on total precipitation $(1144 \mathrm{~mm})$, number of events (110), and maximum event depth ( $81 \mathrm{~mm}$, return period $1.6 \mathrm{y})$ and intensity $(21.6 \mathrm{~mm} / \mathrm{h})$. Figure 21.9 shows all events that occurred during 1967 , ranked by decreasing volume, and the volume of the seven storms used for calibration. All but two of 110 events in 1967 had rainfall depths smaller than 


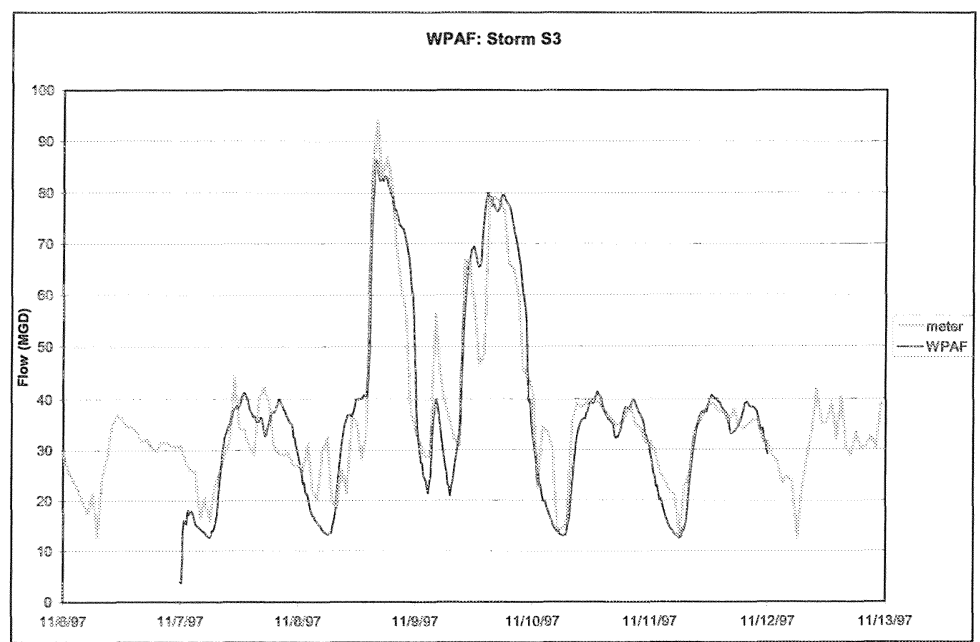

Figure 21.8 Calibration of Storm 3 (meter: measured flows, WPAF: modeled flows).

6.0

S6 - $5.64^{n}$

5.0

$55-4.32^{\prime \prime}$

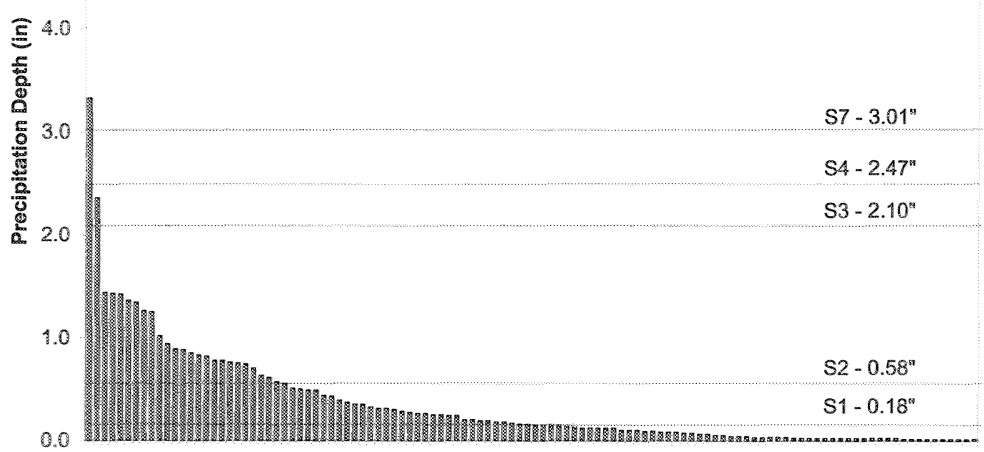

Figure 21.9 Ranking of rainfall events for "average" year 1967.

that of storm S3. Thus, if the model's calibration is confirmed for storms of up to the depth of $S 3(2.10$ inches $/ 53.3 \mathrm{~mm})$, the figure suggests that it will perform satisfactorily for 108 out of 110 events included in the annual simulation.

For further verification of overflow, blocks were placed on overflow weirs to monitor whether overflows occurred due to rainfall. If these blocks had moved during an event, it was an indication that an overflow had occurred. Figure 21.10 is a summary of the CSO block test results. It can be seen that 


\begin{tabular}{|c|c|c|c|c|c|c|c|c|c|c|c|c|c|c|c|c|c|c|c|c|c|c|c|c|c|c|c|c|c|c|}
\hline $\mathrm{CsO} \#$ & Location & $\begin{array}{l}0 \\
8 \\
8 \\
8 \\
0\end{array}$ & $\begin{array}{l}8 \\
\frac{8}{5} \\
\frac{5}{8}\end{array}$ & $\begin{array}{l}8 \\
8 \\
\frac{8}{8} \\
\end{array}$ & $\begin{array}{l}8 \\
8 \\
8 \\
8 \\
\end{array}$ & 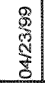 & $\begin{array}{l}8 \\
8 \\
8 \\
8 \\
\end{array}$ & 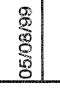 & $\begin{array}{l}0 \\
\text { 罗 } \\
\text { : } \\
\text { : }\end{array}$ & $\begin{array}{l}\frac{g}{8} \\
\frac{1}{0} \\
\end{array}$ & $\begin{array}{l}8 \\
8 \\
5 \\
\end{array}$ & 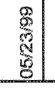 & \begin{tabular}{l}
8 \\
$\frac{8}{2}$ \\
\multirow{2}{*}{} \\
8
\end{tabular} & $\begin{array}{l}0 \\
0 \\
5 \\
5 \\
5 \\
0\end{array}$ & $\begin{array}{l}\frac{2}{3} \\
\text { है } \\
\vdots \\
0\end{array}$ & 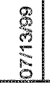 & $\begin{array}{l}\text { \% } \\
\stackrel{5}{*} \\
\stackrel{5}{5} \\
\end{array}$ & 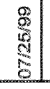 & 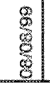 & $\begin{array}{l}8 \\
8 \\
8 \\
8\end{array}$ & $\begin{array}{l}\frac{9}{3} \\
8 \\
8\end{array}$ & $\begin{array}{l}8 \\
\frac{9}{9} \\
\\
8\end{array}$ & 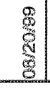 & 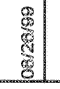 & $\begin{array}{r}8 \\
8 \\
8 \\
8 \\
\end{array}$ & $\begin{array}{r}8 \\
5 \\
8 \\
8\end{array}$ & $\begin{array}{l}0 \\
9 \\
9 \\
8 \\
0\end{array}$ & $\begin{array}{l}\frac{8}{8} \\
\frac{8}{8} \\
0\end{array}$ & $\begin{array}{l}\frac{2}{2} \\
\frac{5}{5} \\
\frac{5}{8} \\
\end{array}$ & 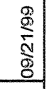 \\
\hline & Total rainfall (in) & 0.40 & 0.23 & 0.26 & 0.04 & 0.51 & 0.20 & 0.04 & 0.07 & 0.14 & 0.71 & 0.72 & 0.89 & 0.66 & 0.25 & 0.09 & 0.13 & 0.06 & 0.51 & 0.45 & 0.26 & 0.82 & 0.30 & 0.75 & 0.18 & 0.08 & 0.33 & 1.42 & 2.48 & 0.33 \\
\hline & Max Intensity (in/hr) & 0.14 & 0.11 & 0.16 & 0.02 & 0.14 & 0.08 & 0.03 & 0.04 & 0.06 & 0.29 & 0.12 & 0.30 & 0.62 & 0.19 & 0.03 & 0.13 & 0.06 & 0.35 & 0.16 & 0.18 & 0.62 & 0.11 & 0.21 & 0.16 & 0.07 & 0.14 & 0.37 & 0.39 & 0.10 \\
\hline & Rainfall Duration (hr) & 9.5 & 6.0 & 10.5 & 2.5 & 7.0 & 24.5 & 2.0 & 13.0 & 5.5 & 18. & 12.0 & 5.0 & 1.5 & 7.5 & 6.0 & 1.0 & 0.5 & 2.0 & 11.5 & 4.5 & 9.0 & 6.0 & 7.5 & 5.0 & 1.5 & 4.5 & 15.0 & 36.0 & 10.5 \\
\hline 002 & Blvd@Lamberton & & & & & & & $\mathrm{N}$ & 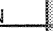 & 8 & & & & & $\mathrm{~N}$ & & $\mathrm{~N}$ & $\mathrm{~N}$ & N & $\mathrm{N}$ & y. & & y. & & & N & & N & (1) & 1.2 \\
\hline 003 & Blvd@Orange & $y$ & 1. & 1. & $\mathrm{~N}$ & 1.2 & 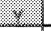 & $\mathrm{N}$ & $\downarrow$ & is & & v. & & y & y & $y$ & v & v. & y. & $\mathrm{N}$ & y & & v. & y & & y & & 1. & 2. & 12. \\
\hline 004 & Blvd@Legion & i) & $y$ & 4 & $\mathrm{~N}$ & y & $\mathrm{N}$ & $\mathrm{N}$ & 1 & $y$ & & 3 & & y & y & $\mathrm{N}$ & $y$ & $y$ & 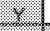 & $\mathrm{N}$ & Y. & & Y & y & & y & & 1. & 1. & 3. \\
\hline 005 & Blvd@Derby & Y. & 2 & $y$ & $\mathrm{~N}$ & 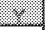 & $x$ & $\mathrm{~N}$ & $\sqrt{2}$ & $y$ & & $y$ & & x & $y$ & $y$ & 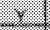 & $y$ & $y$ & $y$ & x. & & $x$ & & & y & & 2 & 3. & 2 \\
\hline 006 & Whallev@Fitch & & & & & & $\mathrm{N}$ & $\mathrm{N}$ & $v$ & 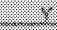 & & Y & & $\mathrm{N}$ & $\mathrm{N}$ & $\mathrm{N}$ & $y$ & y & $N$ & $\mathrm{~N}$ & $y$ & & $\mathrm{~N}$ & N & & y & & 3 & 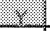 & $\mathrm{N}$ \\
\hline 008 & Munson @ Orchard & & & & & $\mathrm{N}$ & 3 & $\mathrm{~N}$ & $\checkmark$ & x & & $y$ & & $\mathrm{~N}$ & $\mathrm{~N}$ & $\mathrm{~N}$ & $\mathrm{~N}$ & $y$ & $y$ & $\mathrm{~N}$ & $\mathrm{~N}$ & & $\mathrm{~N}$ & $y$ & & y & & $\mathrm{N}$ & $\mathrm{N}$ & $\mathrm{N}$ \\
\hline 009 & Grand@James & $\mathrm{N}$ & $\mathrm{N}$ & $\mathrm{N}$ & $\mathrm{N}$ & $\mathrm{N}$ & $\mathrm{N}$ & $\mathrm{N}$ & $v$ & 4 & & $\mathrm{~N}$ & & $\mathrm{~N}$ & $\mathrm{~N}$ & $\mathrm{~N}$ & $\mathrm{~N}$ & $\mathrm{~N}$ & $\mathrm{~N}$ & $\mathrm{~N}$ & $\mathrm{~N}$ & & $\mathrm{~N}$ & $\mathrm{~N}$ & & N & & $\mathrm{N}$ & 8. & $\mathrm{~N}$ \\
\hline 010 & $\begin{array}{l}\text { East St @ } 1-91 \text { (upstream } \\
\text { weir) }\end{array}$ & 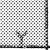 & $\mathrm{N}$ & $\mathrm{N}$ & $\mathrm{N}$ & $\mathrm{N}$ & $\mathrm{N}$ & $\mathrm{N}$ & $v$ & $\mathrm{~N}$ & & $\mathrm{~N}$ & & $\mathrm{~N}$ & $\mathrm{~N}$ & $\mathrm{~N}$ & . & $\mathrm{N}$ & y & $\mathrm{N}$ & y & & $\mathrm{N}$ & $\mathrm{N}$ & & $\mathrm{N}$ & & : & : & $\mathrm{N}$ \\
\hline 010 & $\begin{array}{l}\text { East St @ 1-91 } \\
\text { (downstream weir) }\end{array}$ & & & & & & & $\mathrm{N}$ & & $\mathrm{N}$ & & $\mathrm{N}$ & & $\mathrm{N}$ & $\mathrm{N}$ & $\mathrm{N}$ & $\mathrm{N}$ & $\mathrm{N}$ & $N$ & $\mathrm{~N}$ & (x) & & $\mathrm{N}$ & & & N & & : & . : : & $\mathrm{N}$ \\
\hline 011 & Humphrev@1-91 & & & $\mathrm{N}$ & $\mathrm{N}$ & .2 & 12 & $\mathrm{~N}$ & & $x$ & & $y$ & & & $\mathrm{~N}$ & $\mathrm{~N}$ & y & y. & 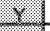 & $\mathrm{N}$ & y & & v & y & & y & & 2. & 8 & 1. \\
\hline 012 & Mitchell@ Nicoll & & $\mathrm{N}$ & 2 & $\mathrm{~N}$ & 1. & 4 & $\mathrm{~N}$ & & N & & y. & & & $\mathrm{N}$ & $\mathrm{N}$ & $y$ & $y$ & $y$ & $\mathrm{~N}$ & $y$ & & $\mathrm{~N}$ & $y$ & & y & & $y$ & 2 & 2. \\
\hline 013 & Everit@East Rock & $\mathrm{N}$ & $\mathrm{N}$ & $\mathrm{N}$ & $\mathrm{N}$ & $\mathrm{N}$ & $\mathrm{N}$ & $\mathrm{N}$ & & x. & & $x$ & & $\mathrm{~N}$ & $\mathrm{~N}$ & $\mathrm{~N}$ & $\mathrm{~N}$ & $\mathrm{~N}$ & $y$ & $\mathrm{~N}$ & $\mathrm{~N}$ & & $\mathrm{~N}$ & N & & N & & $\mathrm{N}$ & $\mathrm{N}$ & $\mathrm{N}$ \\
\hline 014 & Trumbull@ Orange & & & & & 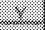 & 12 & $\mathrm{~N}$ & & 12 & & 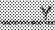 & & 1. & $\mathrm{~N}$ & $\mathrm{~N}$ & $\mathrm{~N}$ & $\mathrm{~N}$ & 1. & $\mathrm{~N}$ & Y & & $\mathrm{N}$ & N & & 1 & & 0. & 3 & 1.2 \\
\hline 015 & James St Siphon & $y$ & $\mathrm{~N}$ & ?. & $\mathrm{N}$ & .5 & $y$ & $\mathrm{~N}$ & & y. & & 4 & & v & $\mathrm{N}$ & $\mathrm{N}$ & $y$ & $y$ & t. & $\mathrm{N}$ & y & & $\mathrm{N}$ & y & & $y$ & & $\mathrm{~N}$ & 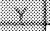 & 1 \\
\hline 016 & River@Poplar & $y$ & $\mathrm{~N}$ & 3 & $\mathrm{~N}$ & . & $y$ & $\mathrm{~N}$ & & y & & $y$ & & v & & $\mathrm{N}$ & & $y$ & y & & $y$ & & & $y$ & & & & 1 & 3 & \\
\hline 018 & Lombard@Front & 2 & $\mathrm{~N}$ & $\sqrt{2}$ & $\mathrm{~N}$ & 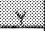 & 1. & $\mathrm{~N}$ & & b. & & 2 & & $y$ & y & $y$ & $y$ & 18 & 1. & y & (1) & & $\mathrm{N}$ & N & & $\mathrm{N}$ & & 1.8 & 2 & 1. \\
\hline 019 & Pine@Front & & $\mathrm{N}$ & $\mathrm{N}$ & $\mathrm{N}$ & $\mathrm{N}$ & $y$ & $\mathrm{~N}$ & 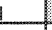 & y & & $y$ & & $y$ & $y$ & $y$ & y & $Y$ & $y$ & $y$ & Y & & 3 & y & & N & & $x$ & 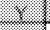 & 4. \\
\hline 020 & Quinnipiac@ Clifton & $\mathrm{N}$ & $\mathrm{N}$ & $\mathrm{N}$ & $\mathrm{N}$ & $\mathrm{N}$ & $\mathrm{N}$ & $\mathrm{N}$ & & $\mathrm{N}$ & & $\mathrm{N}$ & & $\mathrm{N}$ & $\mathrm{N}$ & $\mathrm{N}$ & $\mathrm{N}$ & $\mathrm{N}$ & $\mathrm{N}$ & $\mathrm{N}$ & $\mathrm{N}$ & & $\mathrm{N}$ & N & & $\mathrm{N}$ & & 3 & .3 & $\mathrm{~N}$ \\
\hline 021 & East St PS & & & & & & & N & & y & & $x$ & & y & $\mathrm{N}$ & $\mathrm{N}$ & $\mathrm{N}$ & Y & Y & Y & $y$ & & $\mathrm{~N}$ & & & y & & 1. & 3 & 4. \\
\hline 022 & Allen Place & & & & & . & $y$ & $y$ & & $y$ & & $x$ & & & y & y & Y & $y$ & $y$ & $y$ & $y$ & & $y$ & Y & & y & & 2. & 3 & 12 \\
\hline 024 & Boulevard PS & & & & & 1. & $\mathrm{~N}$ & $\mathrm{~N}$ & & $\mathrm{~N}$ & & $y$ & & & $\mathrm{~N}$ & $\mathrm{~N}$ & $\mathrm{~N}$ & 1. & 4. & y. & Y & & $\mathrm{N}$ & 1 & & 1 & & 1. & 3. & $\mathrm{~N}$ \\
\hline 025 & Union PS & $\mathrm{N}$ & y. & 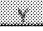 & $\mathrm{N}$ & $x$ & $\mathrm{~N}$ & $\mathrm{~N}$ & & y & & $y$ & & & $y$ & $y$ & $y$ & is & $x$ & y. & Y & & $\mathrm{N}$ & N & & is & & 1. & 3. & .3. \\
\hline N/A & George@.Temple & & & & & $\mathrm{N}$ & $\mathrm{N}$ & $\mathrm{N}$ & & $y$ & & 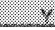 & & $x$ & $\mathrm{~N}$ & $\mathrm{~N}$ & $y$ & $y$ & $y$ & $x$ & $y$ & & y & y. & & y & & 12 & 1. & 1. \\
\hline N/A & Last@ Ives & & & & & & & & & & & & & & & & & & & & $\mathrm{N}$ & & $\mathrm{N}$ & $\mathrm{N}$ & & N & & $\mathrm{N}$ & $y$ & $\mathrm{~N}$ \\
\hline
\end{tabular}

"Note: blocks were not checked between some of the storms, so results in combined columns are for both storms.

1. Block had been moved from its preset location (probably indicating a CSO occurred)

N Block had NOT been moved from its preset location (no CSO)

No data

Figure 21.10 CSO Block Test database. 
the overflow threshold is relatively low. Overflows were affected by rainfall intensity and total rainfall of an event. When the rainfall intensity exceeded 0.75 $\mathrm{mm} / \mathrm{h}(0.03 \mathrm{in} / \mathrm{h})$, overflows began to occur. When rainfall volume exceeded $1.75 \mathrm{~mm}$ (0.07 inches), overflows were observed as well. Databases are strengthened by having a large amount of data. As more data are collected, it becomes easier to spot when an occurrence is an outlier and assign a higher degree of reliability to other data. The block testing data were useful to help pinpoint areas in the model that needed further refinement. However, there were inconsistencies in the database, normal variations in rainfall patterns, and a period of drought during the block monitoring phase that made it difficult to predict the thresholds at which each site would overflow. Over time, as this database continues to be updated, it is expected that it will become a better reference tool that could lead to further refinements of the model. Twelve storms were simulated with the model to verify its ability to predict overflows at each site. In general, the model's predictions and block data showed good agreement regarding the occurrences of CSOs, though the number of storms in agreement varied between sites, ranging between $58 \%$ and $100 \%$ agreement.

The overflow characteristics for the 3-month, 6-month, 1-y and 2-y design storms were simulated with the calibrated model. These design events provided a "snap shot" assessment of the performance of the CSO system and the distribution pattern of critical overflows and their locations. The computer execution time for design events was much shorter than that for an annual event simulation, thus allowing a quicker assessment of potential control approaches. The calibrated model was modified to include upcoming sewer separation projects and field changes to regulators to form a "baseline" model for use in developing the long-term control plan.

Results of the annual event simulation and corresponding CSO pollutant loadings were compared with observed water quality in the receiving waters. The annual simulation showed that bacteria loadings due to CSOs would be quite significant in the Mill River, West River, and Quinnipiac River. However, for the Quinnipiac River and Mill River, pollutants from upstream sources constituted the largest portion of BOD, TSS, and TN loads, indicating that CSOs did not significantly increase the loads on an annual basis. These modeled results corresponded with the water quality data collected in these three receiving streams. In New Haven Harbor, pollutant loads indicated a significant impact from upstream sources for all parameters except fecal coliform loads during individual storm events. During single storm events, such as design storm events, the sudden effect of pollutant loadings from the beginning of a storm on the receiving streams (sometimes known as the "first flush") is more pronounced than on an annual basis. This demonstrates the effect of short "event" loadings during a single storm. 


\subsection{Alternative Evaluation}

Based on the results of the design storm and annual event simulation, control alternatives for meeting the Nine Minimum Controls criteria and the long term control plan were evaluated. Specific use of the results generated with the calibrated model included:

- reviewing overflow statistics (volume, frequency, duration) and estimating associated pollutant loads under varying storm conditions for prioritizing controls,

- identifying system performance problems, such as surcharging, basement flooding, and sediment accumulation,

- estimating how short term controls may improve system performance, such as reducing wet weather surcharging, eliminating dry weather overflows, or maximizing conveyance to the East Shore WPAF,

- estimating the impacts of roof leader connections to the combined and partially separated sewer systems, and identifying a plan for managing roof leader connections and disconnections, and

- evaluating the potential impacts of long term controls on the reduction of overflows and pollutant loads to the receiving waters.

Short-term controls for elimination of those regulators with minor overflows by adjusting the weir level or orifice opening area of the overflow regulator were included. Other options included upgrading the capacity of restricted pipe sections and modifying pump station capacities or pump operations to reduce surcharge.

Public meetings were held to provide public involvement and understand the issues and criteria for selection of alternatives. Meeting water quality standards was found to be the stakeholders' top ranking criterion (CH2MHILL, January 1999). This issue was followed by protection of sensitive areas and elimination of dry and wet weather overflows. Criteria with lower rankings include maximizing aquatic habitat, conveyance, and wastewater treatment facility capacity; protecting wildlife; providing for recreational use; reducing nutrient loads and floatables; eliminating sewer backups, minimizing O\&M costs, improving local parks, and providing for clean streets. Figure 21.11 shows a summary of the ranking of control technologies based on the stakeholders' criteria. The first column (BEST) shows the relative weightings of six criteria selected for consideration. Water quality and system conveyance improvements had the highest weightings. The remaining columns show the alternatives ranked in descending order based on the weightings they received. 
Storage and modification of the Wastewater Pollution Abatement Facility received high rankings as compared to sewer separation and high rate treatment with vortex separators. The next step was to finalize the short term and long term control plans. Technologies selected for further evaluation included closed concrete tanks and chlorination/dechlorination, upland stormwater storage, below ground CSO storage, and treatment facility modifications. Cost-benefit analyses were carried out for specific site control plans and identification of technologies for varying levels of control.

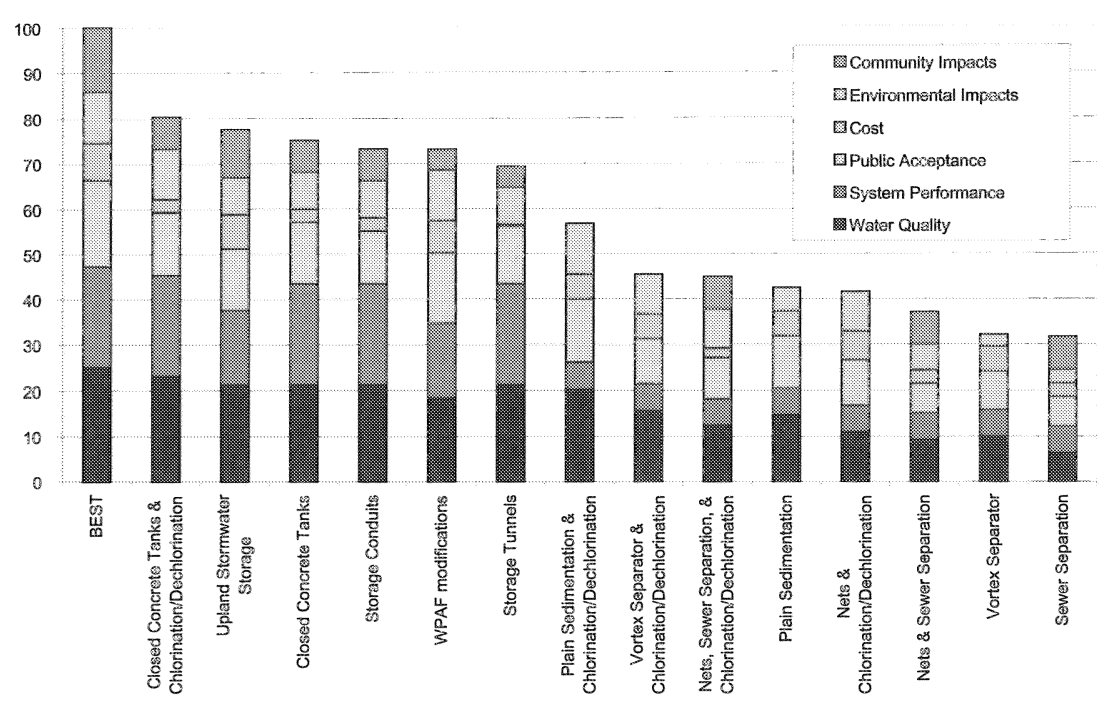

Figure 21.11 Ranking of selection criteria.

\subsection{Conclusion}

The use of electronic databases and GIS greatly increased the speed and accuracy of preparing input data for computer modeling. The input data could be checked and corrected outside of the computer model, thus reducing the amount of time required to debug the model.

The analysis of short and long term control alternatives focused on combination of improving the conveyance capacity of the collection system and the storage of overflows. Pipe and pump capacity upgrades, as well as off-line storage, were found to be the potential solutions. Removal of sediment was not as effective. The recommended control alternatives would affect the capacity 
of the WPAF by allowing more wet-weather flow to be conveyed to the treatment plant. Modification of the facility would be needed. While some relatively minor upgrades to the treatment plant were estimated to be costeffective, a significant capacity upgrade would not be. Therefore, reducing inflow/infiltration in the conveyance system by removing some roof and catchbasin connections would be attractive.

\section{Acknowledgments}

Funding for this project is provided by the New Haven Water Pollution Control Authority, the City of New Haven, and the State of Connecticut Department of Environmental Protection. The authors would like to acknowledge City and WPCA staff for their cooperation and contribution to the project. The CH2M HILL engineering team for the study includes Peter von Zweck (Project Manager), Cliff Bowers, Rita Fordiani, Jamie Maughan, Chris Goz, Perrin Niemann, Rob Meyer, and Philip Cheung.

\section{References}

Cardinal Engineering Associates, Inc. 1981. Facility Plan, Sewage Collection System. Volume 1. Meriden, CT: Cardinal Engineering Associates.

Cardinal Engineering Associates, Inc. 1988. Update and Supplement to Facility Plan for Elimination of Combined Sewer Overflows. Meriden, CT: Cardinal Engineering Associates.

CH2MHILL. March 2000. City of New Haven Long-Term CSO Control Plan. Technical Memorandum \#6, Hydraulic Characterization Report. Boston, MA: CH2MHILL.

CH2MHILL. January 1999. City of New Haven Long-Term CSO Control Plan. Technical Memorandum \#12, Preliminary Evaluation of CSO Control Alternatives. Boston, MA: CH2MHILL.

CH2MHILL. December 1998. City of New Haven Long-Term CSO Control Plan. Technical Memorandum \#3, System Inventory and Model Results. Boston, MA: CH2MHILL.

CH2MHILL. March 1998. City of New Haven Long-Term CSO Control Plan. Technical Memorandum \#5, Monitoring Program Results. Boston, MA: CH2MHILL.

CH2MHILL. July 1997. City of New Haven Long-Term CSO Control Plan. Technical Memorandum \#2, Database Design and System Modeling Approach. Boston, MA: CH2MHILL.

Connecticut Department of Environmental Protection (CTDEP). No Date. Water Quality Standards. Surface Water Quality Standards Effective May 15, 1992. Ground Water Quality Standards Effective April 12, 1996. Hartford, CT: CTDEP. 
United States Environmental Protection Agency (US EPA). 1995. Combined Sewer Overflows, Guidance for Nine Minimum Controls. EPA 832-B-95-003. Washington, D.C.: US EPA.

United States Environmental Protection Agency (US EPA). 1994. Combined Sewer Overflow (CSO) Control Policy. Federal Register, Vol. 59, No. 75. FR Doc. 94-9295. Washington, D.C.: US EPA. 